\title{
Motivating Sentiments and Conflict
}

Two traces of Pareto in Merton's effort toward a theory of reference groups

\section{Carmelo Lombardo}

\section{(2) OpenEdition \\ 12 Journals}

\section{Electronic version}

URL: http://journals.openedition.org/ress/2621

DOI: $10.4000 /$ ress.2621

ISSN: $1663-4446$

\section{Publisher}

Librairie Droz

\section{Printed version}

Date of publication: 15 December 2013

Number of pages: $213-235$

ISBN: 978-2-600-01805-0

ISSN: 0048-8046

\section{Electronic reference}

Carmelo Lombardo, « Motivating Sentiments and Conflict », Revue européenne des sciences sociales [Online], 51-2 | 2013, Online since 01 January 2017, connection on 20 March 2020. URL : http:// journals.openedition.org/ress/2621 ; DOI : https://doi.org/10.4000/ress.2621 


\title{
MOTIVATING SENTIMENTS AND CONFLICT \\ TWO TRACES OF PARETO IN MERTON'S EFFORT TOWARD \\ A THEORY OF REFERENCE GROUPS \\ CARMELO LOMBARDO \\ Sapienza University of Rome carmelo.lombardo@uniromal.it
}

\begin{abstract}
The rare references to Pareto by Merton, especially in his effort towards the construction of a theory of reference groups, is an emblematic case of "obliteration by incorporation". The concepts of "motivating sentiments" and "conflict", that can be found in Pareto's work, play a crucial role in Merton's analysis, opening new perspectives in the conceptualization of social environment and social structure as elements of action. The structure of interaction is conceived as a means through which mental schemes and definitions of the situations are selected by the acting subjects.
\end{abstract}

Keywords: Vilfredo Pareto, Robert K. Merton, motivating sentiments, obliteration by incorporation, theory of reference groups, equilibrium, disequilibrium.

Résumé. Le caractère assez rare des références à l'oeuvre de Pareto par Merton, particulièrement dans son effort de construction d'une théorie des groupes de références, est un cas emblématique d'«oblitération par incorporation». Les concepts de «sentiments de motivation» et de «conflit», qu'on peut trouver dans l'œuvre de Pareto, jouent en effet un rôle crucial dans l'analyse de Merton, ouvrant de nouvelles perspectives dans la conceptualisation d'un environnement et de structures sociaux en tant qu'éléments de l'action. La structure de l'interaction y est vue comme un moyen à travers lequel les sujets agissants procèdent à la sélection des schèmes mentaux et définissent les situations dans lesquelles ils se trouvent.

Mots-clés: Vilfredo Pareto, Robert K. Merton, sentiment de motivation, oblitération par incorporation, théorie des groupes de référence, équilibre, déséquilibre. 


\section{A CASE OF OBLITERATED HERITAGE}

Robert K. Merton acknowledged many times the influence that Émile Durkheim, Max Weber, and George Simmel exercised on his training and his early work. But he never referred to Vilfredo Pareto. ' Yet, Pareto's influence on the young Merton is clear, and some of his issues, though faced with a completely different sociological style of reasoning, crossed and characterized Merton's thought. In fact, some of the focal elements of Merton's sociology, i.e. motivating sentiments and conflict, are also central in Pareto's sociology. Furthermore, Merton never acknowledged how his paradigm of functional analysis was very close to the way in which Pareto had discussed the problem of utility. ${ }^{2}$ Why did not Merton recognize this? Essentially for two reasons. The first, concerns the mechanism of obliteration by incorporation-OBI, in the acronym created by Merton; the second, regards the way in which Talcott Parsons read Pareto.

Obliteration by incorporation is the means Robert K. Merton used to understand and explain the patterns of historical transmission of knowledge. The obliteration of ideas by their incorporation concerns accepted knowledge ${ }^{3}$ and involves the process of selective accumulation of ideas, i.e. the way in which the members

I Reconstructing Merton's familiarity with European sociological thought, Lewis Coser wrote about the influence on Merton's early work of Émile Durkheim, Max Weber, and Georg Simmel (1975, p.96-97). No mention for Pareto.

2 Joseph Lopreato noted that rarely Pareto's system analysis is associated with Merton and his attempts at functional analysis: "A careful comparison of Pareto's discussion of utility with Merton's famous 'paradigm of functional analysis' cannot fail to engage for the high degree of kindredness, though Pareto is not mentionated. Both distinguish, in 'paradigmatic' fashion, between various types of utility [...]. Among these [...] if an individual or a community is subject to various degrees of benefits and detriments, in principle it is possible to find a net utility, what Merton termed a 'net balance of consequences' [...] or [...] the question of 'latent functions' [viewed as] an 'unintended consequence' of action. But how does this differ from Pareto's 'incidental' effects, e.g., obtaining T" while aiming at T?" (2003, p.208). In the same way, Kingsley Davis, in his Presidential address at the American Sociological Association in 1959, pointed out that the distinction between latent and manifest functions "was developed with extreme thoroughness in Pareto's discussion [...] of individual utility and utility to, of, and for the community" (1959, p.765).

3 Robert Merton introduced this idea of "obliteration by incorporation" in the first chapter of his $3^{\text {rd }}$ enlarged edition of Social Theory and Social Structure (1968 [1949]), analyzing the relationship between the history of thought and theoretical systematic (see expecially the 
of scientific communities practice their relationship with the ideas of authors considered classics. So, obliteration by incorporation is a conceptualization of the relationship with the classicality. The quotation from Alfred North Whitehead, chosen as an epigraph for Social Theory and Social Structure (1968 [1949]), is emblematic: "A science which hesitates to forget its founders is lost". To forget the founders means to leave the analysis of their work to the historians of science, and use them only as a starting point to explore and analyze social phenomena, defined in space, time and in their specific conformation of meaning. Is this the fate of Pareto's heritage in Merton's thought? It seems yes: a self-exemplifying case of obliteration by incorporation.

But obliteration by incorporation could apply also to other classics, not only to Pareto. The question remains: why did not Merton recognize the influence of Pareto but acknowledged the influence of other classics? A possible answer involves the process of selective appropriation that affected Pareto's work when his thought was introduced in American sociology (see on this point Chazel, 1999). Pareto had perhaps a decisive influence on the development of the American sociological theory of the first half of nineteenth century. The notions of social system and social equilibrium have become part of sociological vocabulary, giving birth to debates and attitudes which have animated sociology and have, certainly, contributed to its establishment in the public space and in the processes of academic institutionalization. Talcott Parsons and George Homans,

paragraph on Humanistic and Scientific Aspects of Sociology, p.27-30, and that on The Functions of Classical Theory, p.35-38). This idea was best expressed by Merton in the Foreword to Eugene Garfield's Citation Indexing: "Certain patterns of referencing behavior would seem to set limits on the use of citation counts for tracing the long-term genealogy of ideas. One of these patterns has been described as 'obliteration by incorporation': the obliteration of the source of ideas, methods, or findings by their incorporation in currently accepted knowledge. In the course of this hypothesized process, the number of explicit references to the original work declines in the papers and books making use of it. Users and consequently transmitters of that knowledge are so thoroughly familiar with its origins that they assume this to be true of their readers as well. Preferring not to insult their readers' knowledgeability, they no longer refer to the original source. And since many of us tend to attribute a significant idea or formulation to the author who introduced us to it, the altogether innocent transmitter sometimes becomes identified as the originator. In the successive transmission of ideas, repeated use may erase all but the immediately antecedent versions, thus producing an historical palimpsest in which the source of those ideas is obliterated" (Merton, 1979, p.vii). 
two among the best sociologists of that generation, have certainly contributed to the reception of Pareto's thought overseas. ${ }^{4}$ The first, in The Structure of the Social Action (Parsons, 1937), finding him a place in the pantheon of the classics of sociology; the second, writing, in 1934, an introduction to his thought. Both had been part of the so-called Harvard Circle, which, between 1932 and 1934, under the direction of Lawrence Henderson, had read and commented almost the whole work of Pareto. ${ }^{5}$ The leading idea, that these authors shared and that they thought came from Pareto, was that society could be studied as a mechanical model, as a system which contained in itself the tendency to equilibrium, to homeostasis. Henderson, who was a bio-chemist, and influenced Homans in the Thirties (lately, in fact, Homans would have rejected the very possibility of studying the equilibrium of a human group in the same way as we study the organism of an animal affected by an infection) considered homeostatic processes of living organisms as the consequence of Ippocrates's vis medicatrix naturae-a principle according to which organisms have an innate ability of auto-recovery. For Parsons, who comes in contact with Pareto's thought through Henderson, the equilibrium of a system means ultimate ends and value attitudes common to the members of a society as one of the essential conditions of the equilibrium of social systems. In this way, the elements of a social system are for Parsons mean-ends schemes and values rather than residues, interests, derivations, and social heterogeneity as they were in Pareto. The change could

4 The Trattato di sociologia generale was translated in english by Andrew Bongiorno and Arthur Livingstone at the beginning of the 1930s. It was published in four volumes, in 1935, under the title The Mind and Society. Andrew Bongiorno (1930), Lawrence Henderson (1935a; 1935b), Talcott Parsons (1935; 1936a; 1936b), George Homans and Charles Curtis Jr. (1934) wrote reviews of the Trattato. For an analysis of this first steps of the Trattato di sociologia in American sociology and, in general, for an reconstruction and contextualisation of his reception, see expecially Barbara Heyl (1968) and François Chazel (1999).

5 For Barbara Heyl (1968), in the fall of 1932 Lawrence Henderson organized a seminar on Pareto's sociology. The group consisted of George C. Homans, Charles P. Curtis, Jr., Lawrence J. Henderson, Joseph Schumpeter, Talcott Parsons, Bernard DeVoto, Crane Brinton, Elton Mayo, Henry Murray, Clyde Kluckhon, and Robert Merton. Among the members of this seminar, Robert Merton remembers "H.A. Murray and Talcott Parsons, then on the Harvard faculty, Charles P. Curtis, Jr., then of the Harvard Corporation, Kingsley Davis and myself, then graduate students, and George Homans, then an undergraduate" (1977, p. 120). 
not have been more radical: from a conception in which the equilibrium of the social system was conceptualized as a function of the conflict, to one in which it is only a function of consent or of a peaceful coexistence.

Another assiduous frequenter of the seminar on Pareto held by Henderson was the young Robert K. Merton. ${ }^{6}$ His intellectual curiosity lead him to attend the seminar, just like he subsequently would have attended to Parsons' seminars, which were the basis for The Structure of Social Action. As it is well known, Harvard has been described by Merton himself as a microenvironment full of stimuli and intellectual influences, often very different and multi-disciplinary. Pitirim Sorokin - the founding chair of the Harvard Sociology Department - who convinced Merton to move to Harvard to enrich his education and chose him as his research assistant, the science historian George Sarton, Parsons himself, and the Harvard Circle are the knots of a complex net of relationships, influences and socio-cognitive contexts that Merton will develop and widen more and more. Despite the importance that Sorokin and Sarton had in the development of Merton's scientific and cognitive interests, Parsons and the group of Herderson influenced to a greater extent his style of reasoning and of sociological analysis. As Craig Calhoun has written in the introduction of a volume dedicated to Merton published in 2010, and specifically referring to the experience he made in Hendersons' seminar, "Pareto's idea of 'motivating sentiments' was an enduring influence” (Cahloun, 2010, p.2)?

6 Following Bernard Baber, Merton designed Henderson as a "cosmopolitan local" (1977, p. I20).

7 The references to Pareto made by Merton in his early period as researcher concern essentially the non anticipated consequences of purposive action, and appeared in his most important publications of that period: The Unintended Consequences of Purposive Social Action, published in 1936, and his dissertation on Science, Technology and Society in Seventeenth Century England, published in 1938. Merton read and cited Pareto in a french translation of the Trattato di sociologia generale. In the first article, Pareto is cited in two different occasions: I) as one of the thinkers who, among others, had treated the problem of the unanticipated consequences of purposive action (1936, p.894, n. I); 2) in relation to the problem of discriminating between rationalization and truth. In the latter, Merton introduced the problem of post-factum explanations in connection with the way in which Pareto had introduced the problem of chance in paragraph 1977 of his Trattato (p.897, n.9). More complex, as we will see, are the references to Pareto in Science, Technology and Society in Seventeenth Century England. 
But, as it is known, Merton developed this idea, which will be crucial for his further scientific work, in a different way than did Pareto and, above all, Parsons. If Henderson and Parsons, especially the latter, had introduced Merton to the knowledge of European sociological thought, he started nonetheless to mark a distance from their way of approaching the sociological ideas of classics. Rather than in accordance, Merton built his sociological identity in disagreement, for difference rather than for identity. Especially from Parsons: "although much impressed by Parsons as a master-builder of sociological theory, I found myself departing from his mode of theorizing" Merton wrote remembering those years (1994, p.16, italics added).

During the years, he built his method of doing sociology in an opposite way than Parsons and Pareto did: to the formulation of large scale and abstract theories, and to the construction of systems from the top down, he contrasted the careful and patient activity of the empirical researcher theorist, who creates conceptual tools and middle-range theories to focus the results of empirical researches, and to interpret them beyond the immediate data, and, at the same time, uses empirical research to test theoretically fruitful ideas.

Pareto's idea of motivating sentiments was one of these: a fruitful idea on the theoretical level that, however, needed to be applied to research strategies - possibly systematic ones. Science, Technology and Society in Seventeenth Century England, published in $1938^{8}$, represents the place in which the whole of Merton's sociological knowledge is represented. As Steven Shapin (1987) has noticed, Pareto plays a crucial role in the construction of this dissertation, especially with regard to the role that the sentiments-i.e. value ideas, conceptual sche-

8 In 1936 Merton submitted his dissertation to his doctoral committee at Harvard. That committee included George Sarton, Lawrence Henderson, Pitirim Sorokin and Talcott Parsons (see Cole and Zuckerman, 1975, p. 144- 145). A revised version of Merton's dissertation appeared as a monograph in Sarton's series Osiris. Remembering this fact, Merton wrote: "Like other newly minted Ph.D's in those Depression year of the 1930s, I had just about accepted the fact that if my dissertation was to get into print, I should have to (yet obviously could not) subsidize its publication. But then Sarton intevened with the astonishing offer to publish Science, Technology, and Society in Seventeenth-Century England in the monograph series he had just established as a complement to Isis: entitled, naturally enough, Osiris: Studies on the History and Philosophy of Science, and on the History of Learning and Culture. I did not refuse the offer" (1977, p.64). 
mes, ideological articulations - play within the so-called "Merton thesis". In this sense, the whole of the constitutive values of Puritanism, starting from sermons, reflected and reinforced the dominant sentiments. ${ }^{10}$ So, Puritanism represents not only a corpus of ideas that direct action into specific ways, but especially the choice between alternative ways of action, all equally compatible with underlying sentiments. For Merton, "without such guidance and direction, non-logical action would become, within the limits of the valuesystem, random" (1938, p.450)."

The most important aspect of Merton's interpretation of Pareto regards the distinction between residues and derivations, that, for Merton, are operationally separated by an uncertain line because, in practice, "once aware of the strong emotional charge which certain religious convictions carried at the time, we may find it justifiable to treat these as residues rather than derivations" (1938, p.450, n.30). In this way, Merton introduces a remarkable difference from Pareto: to treat mental schemes, ideological convictions, and systems of ideas as residues rather than derivations, as constant elements that provide motivations for behavior rather than variable elements near to post factum justifications. In order to make this effort successful, the underlying sentiments must be treated as psychological statements immediately understandable rather than individual dispositional attitudes or elements of a complex mentality. ${ }^{12}$

9 Steve Shapin (1987) and Gary Abraham (1983) pointed out that the historians misunderstood Merton's thesis because they undervalued the crucial role of motivating sentiments in Science, Technology, and Society in Seventeenth-Century England.

10 This is one of the five citations of Pareto (Merton, 1938, p.419, n. 10). The sermons represent for Merton, who in this way follows Radcliffe-Brown, Malinowski, Durkheim, and Pareto, expressions of the sentiments and values which permeated the thought and action of believers.

II The source for the reference to non-logical action is clearly Pareto. Following the philosopher Rudolf Carnap in relation to the irrational sources of thought, Merton remarked "that the social sciences must locate the irrational (rather, non-logical) sources of both rational and irrational thought" (1938, p.469, n.72).

12 This point was focused by Raymond Boudon (1990), and by Lazarsfeld (1975, p.53-56). As Boudon noted, in the case in which the motivations of actors are introduced as dispositional attitudes "one can easily have the impression that the explanation is tautological" (ibid., p. 120). 


\section{FROM SOCIAL ENVIRONMENT AS PREDISPOSITION TO SOCIAL ENVIRONMENT AS ELEMENT OF ACTION}

Only from the beginning of the 1940's, when he was called to Columbia University, and after that he had started his collaboration with Paul Lazarsfeld, this idea of constant elements that provided to motivating sentiments became a research program, both theoretical and empirical, to the point that it is present in all his work in the following years. However, the way in which Merton used this idea had nothing in common neither with any Paretian residues nor with Parsons' pattern-variables model. In other words, it was necessary to individuate in the structure of interaction which mental schemes and which definition of the situation were selected by the acting subjects, and which consequences they produced-anticipated, non anticipated, positive or negative. The creation of a theory of behavior according to reference groups, which could connect the extreme variability of the data gathered by systematic empirical research, is an emblematic case of conceiving constant elements and motivating sentiments as research-problems. After the appearance of the first two volumes of The American Soldier (Stouffer, 1949), Merton worked on the theoretical idea of reference group. In this effort, he changed his approach to the social environment as source of action. So, Merton conceptualizes social environment as an "element within the core process of action as a direct object of study", rather than a predisposition, to the point that "one could interpret Merton's several approaches to the 'social structure' as an increasing widening of the 'stimulus' idea" (Lazarsfeld, 1975, p.54 and p.56). As it is known, "stimulus idea" for Paul Lazarsfeld is equivalent in meaning to "motivating sentiments".

The basis for the development of the theory of behavior according to reference groups is the wide variety of systematic empirical data made available through a thorough review of the first two volumes of The American Soldier. ${ }^{13}$ The general idea is that some of the interpretations as contained in the original

13 In the following pages are synthesized the main results discussed by Merton in chapter X (written with Alice Kitt Rossi and originally published in Continuities in Social Research. Studies in the Scope and Method of "The American Soldier", edited by Merton and Lazarsfeld in 1950) and in chapter XI of Social Theory and Social Structure (1968 [1949]), $3^{\text {rd }}$ enlarged edition, p.279-440. 
research report, although they would allow to account for multiple, conflicting and seemingly paradoxical data structures, however, were not able to identify any invisible uniformity of social processes capable of integrating all of these interpretations. Analyzing again the main empirical results, Merton, with the assistance of Alice Kitt Rossi, assumed that it is possible to make, along with the interpretations based on psychological and cognitive models of the two concepts in question, also an interpretation based on sociological models, in the sense of an analysis of "their modeling by the social structure in which they occur". The behavior and attitudes of the subjects, in this case, are not only studied as dispositional effects, but as positional and relational effects.

Proceeding towards a new analysis of the main research results of The American Soldier, organizing and systematizing the form of specific contributions to the theory of reference groups, Merton specifies what constitutes such a theory and how it is related with the notions of "relative deprivation", "social reference scheme", "models of expectations" and so on. First of all, the problem is to put in evidence under what specific conditions processes are activated that can be interpreted as "relative deprivation", "social reference schemes" are established and "models of expectations" are structured and "situations" in which individuals are involved are "defined" in one way rather than another. Why, in other words, among the many possible social reference schemes or potential alternatives to models of expectations, subjects choose those rather than others? And what conditions facilitate or hinder the selection?

The simultaneous belonging of individuals to different groups (or, in general, their holding of multiple positions within society, which Merton defines as status-set) forces the sociologist to define, case by case, with which group, among the many to which the individual belongs (or aspires to belong), he establishes any form of comparison or evaluation of his situation. Since multiple affiliations and multiple reference groups are possible, the theory of behavior according to reference groups covers both the cases in which the selection of the groups occurs among groups to which individuals belong, and also the cases in which it occurs among groups to which they do not belong. 
Being dynamic processes, the identification of these processes of selection is only possible in the case where the researcher is able to specifically "characterize the structure of the social situation" within which the different memberships and/or non-memberships are selected as meaningful contexts of comparison. In this way, he will be able to interpret and explain apparently anomalous and paradoxical results. Three examples, drawn from The American Soldier, illustrate the task that Merton assigned to the theory of reference groups.

The first of these examples, which has now become a classic, concerns the satisfaction with reference to the promotion system expressed by soldiers of some military bodies (such as the Military Police) where promotions were rare, in comparison to the dissatisfaction expressed by soldiers in other military bodies (such as the Air Corps) where promotions were more frequent. All things being equal, maintaining levels of seniority, rank and education constant, the data structure provided an interesting problem of interpretation. Only the reconstruction of a possible causal chain can provide this explanation. Since a high social mobility (career advancements) may increase excessively the level of expectations of the members of a group, then they are more likely to experience a sense of acute frustration with regard to their present positions and of dissatisfaction with regard to their future possibilities of mobility. However, this possible explanation considers only partially the multiplicity of social situations potentially associated with this situation. For example, all things equal, in the structuring of evaluations, which mobility rates will prevail: those that exist among individuals who are "in the same boat" or those that exist among individuals who are not "in the same boat"? And, in what conditions, referable to the structure of social situations, does an evaluation derived from a comparison with the successes (or failures) of other individuals considered significant give rise to feelings of frustration and personal inadequacy or produce feelings of injustice in relation to the functioning of those institutions that should ensure the relationship between individual merit and social reward?

The second example illustrates how the response patterns of recruits transferred to veteran departments seemed, apparently, to follow incidental, badly structured and ambiguous changes. Since the recruits could find themselves in two completely different social structures, in homogeneous divisions, composed 
exclusively of recruits, or in divisions composed of veterans, the research identified three possible types of soldiers: recruits in divisions of only recruits, recruits in divisions of veterans and veterans in these divisions. Aptitude questions were put to the soldiers of these groups concerning their will to fight, their confidence in their own abilities in assuming the responsibility of leading a team and their judgment of their own physical conditions. As a result, the authors of The American Soldier identified completely different response patterns which, beginning from the recruits in divisions of veterans, can be briefly summarized as follows. In the first case, the will to fight, their responses rates approached those of veterans and were distant from those of the other recruits in homogeneous departments; in the second case, the confidence in ability to command, their response rates were very distant from those of veterans and significantly distant from those of other recruits; in the third case, the judgment of physical conditions, the response rates of the two groups of recruits were almost super-imposable.

Why do the data show this structure? Why so significant a difference in the first two cases between soldiers who had the same characteristic of being recruits, though differed with respect to the group in which they found themselves, and no difference in the last case? The introduction of a specific hypothesis, derived from the theory of behavior according to reference groups, prevents these response patterns from producing a proliferation of interpretations that, in some cases, are ad hoc and post-factum. The hypothesis is as follows: new members of a group (e.g. the recruits), if motivated, will tend to assimilate the norms (and values) that are typical of the new group (e.g the veterans). Compliance with these norms allows individuals to be accepted by the group as legitimate members, and being considered legitimate members reinforces the trend towards compliance. ${ }^{14}$

14 Within this process, the norms of the most authoritative in the group, comprising especially the values of those whom the new member considers the significant others, are not empty words or abstract configurations but are the way in which individuals come to an evaluation of themselves. Significant others for recruits in homogeneous divisions are individuals with the same level of experience (or, if you will, of inexperience). For recruits in the divisions of veterans they are instead experienced individuals characterized by certain values. It is just the reference to the latter that allows an explanation of the apparent anomalies. 
The third example concerns the occurrence of promotions within the army. Which individuals had the greatest chance of being promoted? Data from a longitudinal study, carried out at different time intervals on three groups of soldiers, had put in evidence that individuals who had expressed attitudes conforming to official military rules had subsequently received promotions at significantly higher rates than soldiers who had not expressed the same attitudes. Therefore, the higher the compliance with rules and practices officially approved by the military, the higher the social mobility. But which individuals adapt better than others to the structure of this situation? Also in this case returns the notion of conformity to norms. However, differently from previously, where compliance was linked to the membership group (the recruits in the divisions of veterans who assimilate the values of the new group), here compliance takes on a perspective value: it is, in fact, used for the purposes of career advancement, or as assimilation of values that characterize a group (of officers) of which the individuals in question are not members but aspire to be. Social conformity here is structurally different from compliance with the standard norms and expectations of the group to which individuals belong. The aspiration of becoming a member of a group one does not currently belong, while it helps to select elements of the regulatory structure of that group to emphasize, in order to adapt and modulate one's own behavior, at the same time produces concrete acts that are not in compliance with the expectations of the group one currently belongs but that comply substantially to the expectations of the group one does not belong. It is the mechanism of anticipatory socialization that makes it possible to select a positive orientation toward groups of non-belonging. This allows us to explain the different rates of promotion within the structure of the army through the identification of the reasons for this difference in the subjective disposition to assimilation of norms typical of a group of non-belonging and through a characteristic of the social structure oriented to reward conformist behaviors rather than merit. As stressed before, the mechanism of anticipatory socialization allows the identification of a positive and subjective anticipation of the assimilation of values that characterize a group of non-belonging and a characterization of the structure of opportunities. It is therefore necessary to 
consider explicitly, along with the positive functions of this mechanism, also the possible consequences that it can (or could) have for the equilibrium of the subject who adopts it and that of his original group of belonging, and for the stability of the entire social structure involved in these processes.

\section{MOTIVATING SENTIMENTS AS MODELS AND LEVELS OF ASPIRATIONS AND OPPORTUNITY STRUCTURE}

As one can easily imagine, these issues, as well as being highly topical, are crucial for the study of two of the most important aspects of complex industrialized societies: models and levels of aspirations, and the configuration of the opportunity structure. How do models and levels of aspirations take shape? How do they relate to the structure of opportunities? Under what conditions do individuals decide to come into play or to abstain? ${ }^{15}$ Returning to our specific example, while a positive orientation towards the official values of the army legitimizes and maintains the structure of authority of the army, at the same time it undermines the solidarity and cohesion of small primary groups to which the soldier belongs. This is because the assimilation of the conflicting norms of another group necessarily means infringement of the norms of the original group, especially in the case where such an infringement may bring about a career advancement within the structure of authority.

Let me consider, first of all, the entire process from the point of view of the individual positively oriented towards a non-membership group of superior status. The mechanism of anticipatory socialization would have a positive consequence for the individual only within an open social structure, that is a social structure allowing actual mobility, while it would have a negative and destabilizing effect to the individual within a closed social structure. But the distinction is purely analytical, since in empirical concreteness the two systems are often

I5 As in the last example discussed, it is a game in which the individual may lose everything, in which he risks finding himself in a perpetual no man's land, out of his own original group of belonging and rejected by the group of non-belonging to which he aspires. It is a game that not only affects the individual, but also has consequences for both the original group of belonging and the whole social structure. 
mixed and without a clear-cut line of discrimination. Not only are there relatively open social structures and relatively closed social structures but, paraphrasing Merton, one might say that it would be necessary to investigate the relativity of the openness or closedness of such systems. This is the well-known issue affecting complex societies which are considered open societies with a strong social mobility. But what determines the practicability of ascending the social structure? In the example we are considering, that of promotion rates, it would seem to depend on a conformist assimilation of the norms of the structure of authority rather than an impartial recognition of individual merits. If you add to this the perception, by some soldiers, of a discretionality inherent in the assessment of the officials in charge of career advancement, designed to interpret the assimilation of the official norms of the military in a declination of personal submission and sacrifice of individual autonomy, the matter is further complicated. On the one hand, there is the functioning of the social structure, and on the other, consequently, the emergence of a feeling that can be articulated in many, varied and even contradictory ways. Indeed, what do "official norms of the military" really mean? How are these values actually interpreted by officers? What is given more importance, the formal respect of authority or the fulfillment of duty? It is evident that these questions can only be answered through systematic empirical research that places them at the center of its inquiry.

However, the basic question remains: which individuals adapt better than others to a specific empirical articulation of promotional systems, given that the structure of opportunities and the system of rewards can be (and actually are) insufficient, inefficient and obstructed in their practicability? Merton had already dealt with these issues in his essay on anomie and social structure, highlighting how, given a need structurally induced, to which, thus, an individual has been socialized (e.g. success), the impracticability of institutionally legitimate means to achieve it may lead to a complex sequence of adaptive individual positions, ranging from the renunciation to rebellion to the eventual use of non-institutionalized and illegitimate means all the way to downright criminal means. Thus relativity in the openness of the social structure can transform positive tension towards 
social progression into frustration, which could result in not only feelings of resignation or rebellion, but even revolutionary movements.

What impact, though, do these processes have on the cohesion of the original groups of belonging and the behavior of individuals that belong to them? We have already mentioned the possible break-up of group cohesion. But what effects do these processes have on individuals in relation to their relationship with the social structure within which these processes take place? ${ }^{16}$

These processes, that are established within specific systems of interaction between individuals in which the courses of individual action take shape, although intentional, or triggered by the reasons that the researcher can reconstruct, are inherently adaptive processes. And it is this thin and invisible thread which holds together concepts such as relative deprivation, anticipatory socialization, social mobility, assimilation of values, conformism, deviance, conflicting pressures, conflict of roles, and which integrates them as adaptive processes within the theory of behavior according to reference groups.

\section{SOCIAL ENVIRONMENT, MOTIVATING SENTIMENTS, AND INDIVIDUAL AUTONOMY: STRUCTURAL SOURCE OF INSTABI- LITY AND CONFLICT}

And so we arrive at a metaphorical knot, that of individual autonomy. If the decision-making processes are adaptive and situated, what is left of individual freedom? How is individual autonomy possible? With difficulty, is the response of Merton, but it is possible. Indeed, the multi-belonging and complexity of social relationships are conditions for its affirmation. Conditions which are, at the same time, of resistance and

I6 For example, what effects will the career advancement of conformists have on the "morale" of the soldiers? Their evaluations will also concern the structure that made those career advancements possible, as well as the possible consequences which, as a result of these subjective assessments, will be produced in terms of anomie and "personal disorganization". In this case, then, the evaluations of their conditions/positions implies a judgment on the fate of significant others and, in the event that this fate were considered better, this would lead to a judgment on its legitimacy. Necessarily, therefore, such a judgment would extend to the social structure that made it possible, to return eventually, in a much more severe form, due to the extra emotional burden that each of these steps involves, to the initial subject. 
adaptation. Also in this case, we can consider two examples: that of non-membership and that of the structural sources of instability in the set of roles.

Why is non-membership so important? Why track down the criteria that identify it? Because it is evident that non-membership does not only concern individuals who do not meet the requirements for membership, but also, and above all, concerns those who, despite being in possession of these requirements, are not part of the group. For these latter individuals, non-membership may be configured either as a mute and neutral absence or as claimed and antagonistic absence. If the absence is claimed and antagonistic, then it would be the source of serious structural imbalances for the group. The subjective disposition to the abandonment of a group of membership in favor of an aspired one of nonbelonging is only one of the possible effects of imbalances, of individual and structural order, that may invest a group. But the strongest pressure that the membership group exerts on individuals arrives when the threatened integrity of the group could compromise its social power. The most dangerous threats to the integrity of the group come from two specific types of non-belonging, from those who meet the requirements for membership but reject it, and from those who have become ex-members. In both cases, as Merton claimed taking explicitly from Simmel, ex-members and those who are eligible for membership and refuse it bring into question the very existence of the group, as they affirm the relativity of its norms, which are therefore disowned and despised by those to whom they should apply. Both plastically symbolize the relative weakness of the group and, correspondingly, undermine its credibility. The ex-members also specifically show the fragility of the loyalty that should anchor the members to the group. Under these perceived threats, and because of the need for integrity in order to wield its social power, the group exerts pressures that are, from the point of view of individuals, very strong. ${ }^{17}$

17 They are particularly strong, of course, concerning ex-members. Since belonging to a group produces profound feelings of attachment, to voluntarily cease to be part of it involves ambivalent feelings and attitudes. What Merton calls a "dual approach" tends to develop where an individual will aspire to belong to a new group, assimilating new relevant norms, and, simultaneously, be at odds with his previous group, to the point of using it as a negative reference framework. Positive and negative reference groups can, in different forms and on different occasions, be taken as models of comparison. 
The fluidity of social processes, the possibility of switching from one group to another, the greater or lesser openness of the groups and the simultaneous membership of an individual to different groups, each with their own norms, value and demands of loyalty, all make the theme of belonging and non-belonging decisive for the purposes of adaptive decision-making processes. For this reason the specification of the conditions within which forms of belonging and non-belonging assume relevance is a strategic operation, and more so for the former than the latter. The typology of non-belonging developed by Merton, who reviews the logical possibilities, not only suggests strategies for empirical testing in order to determine under what conditions and within what social process the emergence of a type of non-membership rather than another is more likely, but it also puts in place a conceptual map whose cells can all be occupied by the same individual at different stages of his life. The sociological braid, that this conceptual map offers in its analytical linearity, emerges as a labyrinth in which it is not easy to determine which system of interaction promotes or inhibits the actualization of each of these potentials. Under what conditions does aspiration fade into indifference or lead to antagonism? And what consequences will each of these individual choices have for the individual himself, for other individuals with whom he relates, for the structure of the groups and for the social structure as a whole? Finally, considering the complexity of these processes and the effect they have on and in determining individual choices, what allows the system to be in an equilibrium, within which the practicability of human and social existence is conceivable?

First of all, the equilibrium is dynamic. This means that the social processes, as such, come into existence, change, break and reform seamlessly. In this sense, they resemble "life processes" according to Georg Simmel. There is no linearity in them, if not the analytic one set by their interpreter. Their characteristic is structural instability, which, however, should not be understood as chaos but as a difficult, provisional and dynamic equilibrium. Analytical tools used to obtain order from empirical disorder must not simply define the form of these processes, but must identify the conditions under which the equilibrium is constantly broken and reassembled. 
This condition is particularly evident in the analysis carried out by Merton regarding the characteristics of the structural context within which the theory of behavior according to reference groups is to be found. Individuals occupy a set of positions within society, each of which originates a set of role relations, which are a direct consequence. The status set and the role set, which according to Merton constitute the elements of the social structure, describe the general state of the social structure as it presents itself at a given moment in time. However, since the positions that an individual will occupy in the course of his life are not established once and for all but are in fact sequential, then we should talk about sequences of statuses and sequences of roles. The status set indicates the set of social orders to which the individual belongs, while the role set identifies the set of structural relationships that characterize the position of the individual within each of these orderings. The multiplicity and variability of roles is the basis for the assertion of individual autonomy (see on this point Laub Coser, 1975).

The starting point is clear: to operate effectively, each and any social structure must organize these status sets and role sets, and sequences of statuses and of roles in order to achieve a certain degree of social order, sufficient to enable the majority of people, for most of the time, to have a regular social life without having to improvise new solutions to each new situation that comes by. The possible role relationships in which the individual is involved are often asymmetrical, as these relationships occur with other individuals differently positioned within the social structure, with consequent diverse and different expectations, values and allocations of power. This derives from the multiplicity and diversity of social relations that characterize roles, but necessarily implies that there is a consequent multiplicity and diversity of requests, often conflicting, in which the individuals are invested. In addition, and as a consequence, for the coexistence of these multiple and diverse social relationships to be possible, the framework of norms and values that governs behaviors concerning the role sets must inevitably be poorly structured, almost ambiguous. Rather than a set of "instructions for use", clearly spelled out and organized, the individual learns socially legitimate adaptive ways, characterized by partiality, discretion and ambivalence because partial, discretionary and ambivalent is the organiza- 
tion of the norms of the role set. In learning these adaptive ways, a crucial role is played by the relationships attributable to systems of interdependence. Since within these relationships it is possible to draw from a common set of unwritten and unformalized expertise and knowledge, they contribute to structure models of interpretation of the norms, models of relational expectations and models of other possible and meaningful role relationships that, once again, lead in the direction of a theory of behavior according to reference groups.

\section{CONCLUSION}

The motivating sentiments and conflict are two focus points of Merton's sociology: the first represent the way in which the interaction context and the social structure intervene in the possibility of a personal choice among socially structured alternatives; the second is, equally, the product of social structures, i.e. of normative structures that contain within themselves sociological ambivalences in the form of structured expectations incompatible among themselves, just like socially structured dyscrasias between personal expectations culturally induced and structured differences in the access to institutional means.

For Pareto, a theory of social equilibrium, built starting from the analysis of the forces that act within society, includes elements such as residues, interests, and so on, which are not harmonic but discordant. ${ }^{18}$ For him, society can be studied "as a system of mutually interacting particles which move from one state of equilibrium to another" (Pareto, 1966, p.31, cited in Heyl, 1968, p.316), but rather than an effort to study society as a system with a built-in homeostatic tendency, as in Parsons' interpretation, the crucial passage is that this system "moves from one state of equilibrium to another". What is there in this passage from one state to another? Disequilibrium, of course, often conflict, sometimes violent conflict. Merton's sociology conceptualizes and focuses this passage.

18 This point has been grasped with great perspicacity by Joseph Lopreato: "One of the most potentially fruitful $[\ldots]$ uses of equilibrium would lead us to conceive of social group as balance of forces precariously cohering in constant contention, ever producing breakdowns in communication, open clashes on interests, redistributions of political and economic advantages, and the like. This is the vision of Pareto's equilibrium sociology". Or, put otherwise, "first examined the problem of class circulation, and then turned to the analysis of equilibrium" (197I, p.343). 


\section{BIBLIOGRAPHY}

ABRAHAM G.A., 1983, "Misunderstanding the Merton Thesis", Isis, p.368-387.

BONGIORNO A., 1930, "A Study of Pareto's Treatise on General Sociology", The American Journal of Sociology, 36-3, p.349-370.

BOUDON R., 1977, "La logique de la frustration relative", in Effets pervers et ordre social, Paris, PUF, p.I3I-I55.

-, 1979, La Logique du social, Paris, Librairie Hachette.

-, 1990, "The Two Facets of the Unintended Consequences Paradigm", in Robert K. Merton: Consensus and Controversy, J. Clark, C. Modgil, S. Modgil (eds), LondonNew York, Falmer Press, p. I19-127.

-, 1999, L'Actualité de la distinction parétienne entre "actions logiques" et "actions non logiques", in Pareto aujourd'hui, A. Bouvier (ed.), Paris, PUF, p.35-70.

CALHOUN C., 2010, "Introduction: on Merton's Legacy and Contemporary Sociology", in Robert K. Merton: Sociology of Science and Sociology as Science, C. Calhoun (ed.), New York, Columbia University Press, p. I-3I.

CAMIC C. (ed.), 199I, Talcott Parsons, The Early Essays, Chicago, The University of Chicago Press.

CHAZEL F., 1999, "L'entrée de Pareto dans la sociologie américaine et son appropriation sélective par Talcott Parsons et George Homans", in Pareto aujourd'hui, A. Bouvier (ed.), Paris, PUF, p. I29-I52.

COHEN B., 1990, "Some Documentary Reflections on the Dissemination and Reception of the 'Merton Thesis"', in Robert K. Merton: Consensus and Controversy, J. Clark, C. Modgil, S. Modgil (eds), London-New York, Falmer Press, p.307-348.

COLE J.R., ZUCKERMAN H., 1975, "The Emergence of a Scientific Specialty. The Self-Exemplifying Case of the Sociology of Science", in The Idea of Social Structure. Papers in Honor of Robert K. Merton, L.A. Coser (ed.), New York, Harcourt, Brace and Co., p.139-174.

COSER L.A., 1975, "Merton's Uses of the European Sociological Tradition", in The Idea of Social Structure. Papers in Honor of Robert K. Merton, L.A. Coser (ed.), New York, Harcourt, Brace and Co., p.85-100. 
DAVIS K., 1959, "The Myth of Functional Analysis as a Special Method in Sociology and Anthropology", American Sociological Review, 24, p.757-772.

ELSTER J., 1983, Sour Grapes. Studies in the Subversion of Rationality, Paris and Cambridge, Maison des Sciences de l'Homme and Cambridge University Press.

FESTINGER L., 1954, "A Theory of Social Comparison Processes", Human Relations, 7, p.I17-140; re-edited in Readings in Reference Group Theory and Research, 1968, H. Hyman and E. Singer (eds), New York, The Free Press, p. $123-146$.

HENDERSON L.J., 1935a, Pareto's General Theory: A Physiologist's Interpretation, Cambridge, Harvard University Press.

-, 1935b, "Pareto's Science of Society", The Saturday Review of Literature, May 25, p. 3-4.

HEYL B., 1968, "The Harvard 'Pareto Circle"', Journal of the History of the Behavioral Sciences, 4-4, p.316-334.

HIRSCHMAN A., 1982, Shifting Involvements. Private Interest and Public Action, Princeton, Princeton University Press.

HOMANS G.C., CURTIS, C.P. Jr., 1934, An introduction to Pareto: his sociology, New York, Alfred A. Knopf.

HYMAN H., 1942, "The Psychology of Status", Archives of Psychology, 269, p.5-91; partially re-edited in, Readings in Reference Group Theory and Research, 1968, H. Hyman and E. Singer (eds), New York, The Free Press, p.147-165.

-, 1960, "Reflections on Reference Groups", The Public Opinion Quarterly, 24-3, p.383-396.

LAUB COSER R., 1975, "The Complexity of Roles as a Seedbed of Individual Autonomy", in The Idea of Social Structure. Papers in Honor of Robert K. Merton, L.A. Coser (ed.), New York, Harcourt, Brace and Co., p.237-263.

LAZARSFELD P., 1975, "Working with Merton", in The Idea of Social Structure. Papers in Honor of Robert K. Merton, L.A. Coser (ed.), New York, Harcourt, Brace and Co., p.35-66. 
LOPREATO J., 197I, "The Concept of Equilibrium: Sociological Tantalizer", in Institutions and Social Exchange. The Sociologies of Talcott Parsons \& George C. Homans, H. Turk, R. Simpson (eds), Indianapolis \& New York, The Bobbs-Merrill Company, p.309-343.

-, 2003, "An Evolutionist Reads Pareto: Homage to Giovanni Busino", in Histoire et théories des sciences sociales. Mélanges en l'honneur de Giovanni Busino, M. Cherkaoui (ed.), Genève, Droz, p. 189-214.

MERTON R. K., 1934, "Recent French sociology", Social Forces, 12,-4, p.537-545.

-, 1936, "The Unanticipated Consequences of Purposive Social Action", American Sociological Review, I-6, p.894-904.

-, 1938, "Science, Technology and Society in Seventeenth Century England", Osiris, 4, p.360-632.

-, 1968 (1949), Social Theory and Social Structure, Glencoe, The Free Press.

-, 1976, Sociological Ambivalence and Other Essays, New York, The Free Press.

-, 1977, "The Sociology of Science. An episodic Memoir", in The Sociology of Science in Europe, R. K. Merton, J. Gaston (eds), Carbondale, Southern Illinois University Press, p.I-I4I.

-, 1979, "Foreword", in E. Garfield, Citation Indexing: Its Theory and Application in Science, Technology, and Humanities, New York, John Wiley.

-, 1987, "Three Fragments from a Sociologist's Notebooks: Establishing the Phenomenon, Specified Ignorance, and Strategic Research Materials", Annual Review of Sociology, 13, p.I-29.

-, LAZARSFELD P.F. (eds), 1950, Continuities in Social Research. Studies in the Scope and Method of "The American Soldier", Glencoe, The Free Press.

NEWCOMB T., 1943, Personality and Social Change: Attitude Formation in a Student Community, New York, Dryden Press.

NICHOLS L.T., 2010, "Merton as Harvard Sociologist", Journal of the History of the Behavioral Sciences, 46-I, p.72-95.

PARETO V., 1988 (1916), Trattato di sociologia generale, Giovanni Busino (ed.), Torino, Utet, 4 vols; translated in English as The Mind and Society, 1935, 4 vols, New York, Harcourt, Brace and Co. 
-, 1966, Sociological Writings, New York, Praeger.

PARSONS T., 1935, "Review of Mind and Society by V. Pareto and Pareto's General Sociology by L. J. Henderson", American Economic Review, 25-3, p.502-508.

-, 1936a, "Pareto's Central Analytical Scheme", Journal of Social Philosophy, I, p.244-262; re-published in Talcott Parsons, The Early Essays, 1991, C. Camic (ed.), Chicago, The University of Chicago Press, p.133-152.

-, 1936b, "Review of by Vilfredo Pareto's Mind and Society", American Sociological Review, I-I, p.139-148.

-, 1937, The Structure of Social Action, New York, McGraw-Hill.

-, 1951, The Social System, Glencoe, The Free Press.

RUNCIMAN W., 1966, Relative Deprivation and Social Justice. A Study of Attitudes to Social Inequality in Twentieth-Century England, London, Routledge \& Kegan Paul Ltd.

SHAPIN S., 1988, "Understanding the Merton Thesis", Isis, 79, p.594-605.

SHERIF M., 1953, "The Concept of Reference Groups in Human Relations", in Group Relations at the Crossroads, M. Sherif and M.O. Wilson (eds), New York, Harper \& Row, p.203-231; re-edited in Readings in Reference Group Theory and Research, 1968, H. Hyman and E. Singer (eds), New York, The Free Press, p.84-102.

SMITH B., 1949, "The Combat Replacement", in The American Soldier, Studies in Social Psychology in World War II, vol. 2, S. Stouffer (ed.), Princeton, Princeton University Press, p.242-289.

STOUFFER S. (ed.), 1949, The American Soldier, Studies in Social Psychology in World War II, 2 vols, Princeton, Princeton University Press.

SUCHMAN E, 1949, "Social Mobility in the Army", in The American Soldier, Studies in Social Psychology in World War II, vol. I, S. Stouffer, (ed.), Princeton, Princeton University Press, p.230-283.

WILLIAMS R., 1975, "Relative Deprivation", in The Idea of Social Structure. Papers in Honor of Robert K. Merton, L.A. Coser (ed.), New York, Harcourt, Brace and Co, p.355-378. 
